\title{
Inhibitors of phosphatidylinositol 3-kinase amplify insulin release from islets of lean but not obese mice
}

\author{
W S Zawalich, G J Tesz and K C Zawalich \\ Yale University School of Nursing, 100 Church Street South, New Haven, Connecticut 06536-0740, USA \\ (Requests for offprints should be addressed to W S Zawalich; Email: Walter.Zawalich@Yale.Edu)
}

\begin{abstract}
We examined the effects of phosphatidylinositol 3-kinase (PI3K) inhibition by wortmannin or LY294002 on glucose-induced secretion from mouse islets. Islets were collagenase isolated and perifused or subjected to Western blot analyses and probed for insulin receptor-signaling components. In agreement with previous studies, mouse islets, when compared with rat islets, were minimally responsive to $10 \mathrm{mM}$ glucose stimulation. The inclusion of $50 \mathrm{nM}$ wortmannin or $10 \mu \mathrm{M}$ LY294002 significantly amplified $10 \mathrm{mM}$ glucose-induced release from mouse islets. The effect of wortmannin was abolished by the calcium channel antagonist nitrendipine or by lowering the glucose level to $3 \mathrm{mM}$. Wortmannin had no effect on $10 \mathrm{mM} \alpha$-ketoisocaproate-induced secretion. In contrast
\end{abstract}

to its potentiating effect on islets from CD-1 mice, wortmannin had no effect on $10 \mathrm{mM}$ glucose-induced release from ob/ob mouse islets. Western blot analyses revealed the presence of the insulin receptor, insulin receptor substrate proteins 1 and 2 and PI3K in CD-1 islets. These results support the concept that a PI3Kdependent signaling pathway exists in $\beta$-cells and that it may function to restrain glucose-induced insulin secretion from $\beta$-cells. They also suggest that, as insulin resistance develops in peripheral tissues, a potential result of impaired PI3K activation, the same biochemical anomaly in $\beta$-cells promotes a linked increase in insulin secretion to maintain glucose homeostasis.

Journal of Endocrinology (2002) 174, 247-258

\section{Introduction}

Often overlooked in studies utilizing mouse islets is the disparity that characterizes this species islet responses to glucose when compared with rat or human islet responses (Gerich et al. 1974, Pagliara et al. 1974, Berglund 1980, O'Conner et al. 1980, Curry 1986, Van Haeften et al. 1990, Elahi 1996). For example, over 30 years ago, it was reported (Malaisse \& Malaisse-Lagae 1968) that glucoseinduced insulin release was reduced from freshly studied, statically incubated mouse pancreatic pieces when compared with rat responses. This difference has since been ascribed to a profound reduction in the magnitude of the second phase secretory response to the hexose from mouse islets (Lenzen 1979, Berglund 1980, Ma et al. 1995, Zawalich et al. 1995b, Seghers et al. 2000). More recent studies have attributed this reduction to alterations in signaling via the phospholipase C (PLC)/protein kinase C pathway (Zawalich et al. 1995b, Zawalich 1996, Zawalich \& Zawalich 1996a). When compared with both the exuberant second phase insulin secretory response (Charles et al. 1973, Henquin \& Lambert 1976, Zawalich et al. 1989b) and robust generation of inositol phosphates (IPs) in studies using rat islets (Best \& Malaisse 1983, 1984, Zawalich et al. 1991), minimal effects are observed in similarly treated mouse islets (Zawalich et al. 1995b, Zawalich 1996, Sato \& Henquin 1998). Species differences in the expression of several PLC isozymes have also been reported and may account for the reduction in both IP accumulation and second phase release from mouse islets (Zawalich et al. 1995b).

Transgenic and knockout mice are being increasingly utilized as models to study the biochemical pathways responsible for the emergence of insulin resistance and their potential involvement in the pathogenesis of type 2 diabetes (Araki et al. 1994, Tamemoto et al. 1994, Kido et al. 2000). These and other studies (Harbeck et al. 1996) have demonstrated that elements of the insulin signaling pathways characterized in peripheral tissues such as liver, muscle and adipose cells (Virkamäki et al. 1999) exist in $\beta$-cells as well. Most recently, it has been reported (Kubota et al. 2000) that islets isolated from insulin receptor substrate-2 (IRS-2)-deficient mice exhibit augmented insulin secretory responses to glucose stimulation. These findings suggest that IRS-2 activation of phosphatidylinositol 3-kinase (PI3K) may participate in a negative feedback system that functions to regulate insulin secretion. Also consistent with the concept that insulin signaling regulates $\beta$-cell secretory responses are many previous studies demonstrating that insulin inhibits its own 
secretion (Iversen \& Miles 1971, Loreti et al. 1974, Ammon \& Verspohl 1976, Liljenquist et al. 1978, Ammon et al. 1991).

We recently demonstrated (Zawalich \& Zawalich 2000) that the fungal metabolite wortmannin, a specific PI3K inhibitor at nanomolar concentrations (Acaro \& Wymann 1993, Okada et al. 1994, Yeh et al. 1995), amplified $8 \mathrm{mM}$ glucose-induced insulin secretion from perifused rat islets. Since PI3K activation by insulin receptor substrate proteins appears to determine liver, muscle and adipose tissue sensitivity to insulin, we suggested that this signaling pathway might provide a means for the $\beta$-cell to monitor insulin sensitivity in peripheral tissues and to adjust their secretory responses accordingly. Because of the existence of pronounced species differences in glucose responses between rat and mouse islets and the almost exclusive use of mice as transgenic models of diseases, we decided to assess the impact of several structurally distinct PI3K inhibitors on glucose-induced release from perifused mouse islets. In addition, mouse islets were subjected to Western blot analyses and probed for the presence of PI3K, the insulin receptor (IR), IRS-1 and IRS-2.

\section{Materials and Methods}

\section{Islet isolation}

The detailed methodologies employed to assess insulin output from collagenase-isolated islets have been previously described (Zawalich \& Zawalich 1988). Male Sprague-Dawley (SD) rats (weight at time of study $350-475 \mathrm{~g})$ and male CD-1 mice (22-38 g) were purchased from Charles River (Raleigh, NC, USA). Female ob/ob mice (40-52 g, stock number 000632, former name C57BL/6J-Lep ob, current name B6.V-Lep ob) and their lean littermates (19-22 g) were purchased from Jackson Laboratories (Bar Harbor, ME, USA). All animals were treated in a manner which complied with the NIH Guidelines for the Care and Use of Laboratory Animals (NIH publication no. 85-23, revised 1985). The animals were fed ad libitum. After intraperitoneal pentobarbital sodium (Nembutal, $50 \mathrm{mg} / \mathrm{kg}$; Abbott, North Chicago, IL, USA)-induced anesthesia, islets were isolated by collagenase digestion and handpicked, using a glass loop pipette, under a stereo microscope. They were free of visual exocrine contamination.

\section{Perifusion studies}

Groups of 14-18 isolated islets were loaded onto nylon filters (Tetko, Inc., Briarcliff Manor, NY, USA) and perifused in a Krebs-Ringer bicarbonate (KRB) buffer at a flow rate of $1 \mathrm{ml} / \mathrm{min}$ for $30 \mathrm{~min}$, usually with $3 \mathrm{mM}$ glucose, to establish basal and stable insulin secretory rates. In experiments with $\alpha$-ketoisocaproate (KIC), glucose was omitted during this time. After this 30-min stabilization period they were then perifused with the appropriate agonist or agonist combinations as indicated in the figure legends and Results section. Wortmannin or LY294002 were dissolved in dimethyl sulfoxide and comparable amounts of this diluent were added to control solutions. Perifusate solutions were gassed with $95 \% \mathrm{O}_{2} / 5 \% \mathrm{CO}_{2}$ and maintained at $37^{\circ} \mathrm{C}$. Insulin released into the medium was measured by RIA (Albano et al. 1972).

\section{Western blot studies}

Freshly isolated islets from CD-1 mice were suspended in a 2:1 ratio of islets per $\mu \mathrm{l}$ of homogenization buffer $(1 \mathrm{mM}$ dithiothreitol, $0.1 \mathrm{mM}$ leupeptin, $5 \mathrm{mM}$ benzamidine, $10 \mu \mathrm{g} / \mathrm{ml}$ soybean trypsin inhibitor, $5 \mu \mathrm{g} / \mathrm{ml}$ aprotinin, $2 \mu \mathrm{M}$ pepstatin A and $2 \mathrm{mM}$ phenylmethylsulfonyl fluoride in $12.5 \mathrm{mM}$ Tris, $1.25 \mathrm{mM}$ EGTA, 1.25 mM EDTA and $0 \cdot 25 \%$ Triton $\mathrm{X} 100, \mathrm{pH} 7 \cdot 6$ ). Islets were then disrupted by sonic oscillation. Duplicate aliquots were analyzed for protein content with the Lowry assay (Lowry et al. 1951) using BSA to generate the standard curve and a rat liver preparation in homogenization buffer as an internal standard. Thirty micrograms of CD-1 islet protein and $20 \mu \mathrm{g}$ of control $3 \mathrm{~T} 3$ cell lysate were separated by SDS-PAGE electrophoresis using a 4\% stacking gel with a $7 \%$ separating gel at $12 \mathrm{~mA}$ and $16 \mathrm{~mA}$ respectively. Separated proteins were electro-transferred onto a polyvinylidene difluoride transfer membrane with $15 \mathrm{~V}$ for $20 \mathrm{~h}$. Transfer was confirmed by staining with Ponceau S. Membranes were then briefly washed with distilled deionized water. PI3K, IRS- 1 and IR $\beta$ subunit membranes were blocked in Blotto A (Tris-buffered saline containing 5\% Carnation non-fat dried milk and 0.05\% Tween 20) for $1 \mathrm{~h} 50 \mathrm{~min}$. IRS-2 membranes were blocked in PBS (pH $7 \cdot 1$ with $3 \%$ Carnation non-fat dried milk). For PI3K, membranes were incubated for 90 min with anti PI3K rabbit antisera (1:2000 dilution), washed, followed by incubation for $45 \mathrm{~min}$ with anti rabbit IgG-horseradish peroxidase (HRP) $(0.5 \mu \mathrm{g} / \mathrm{ml})$ and then washed again. For IRS-1, membranes were incubated for $2 \mathrm{~h}$ with primary antibody, rabbit polyclonal IgG anti IRS-1 $(1 \mu \mathrm{g} / \mathrm{ml})$, washed, followed by incubation for $90 \mathrm{~min}$ with anti rabbit IgG-HRP $(0 \cdot 5 \mu \mathrm{g} / \mathrm{ml})$ and then washed again. For IR $\beta$ subunit, membranes were incubated for $2 \mathrm{~h}$ with anti $\operatorname{IR} \beta$ subunit rabbit $\operatorname{IgG}(1 \mu \mathrm{g} / \mathrm{ml})$, washed, followed by incubation for 90 min with anti rabbit IgG-HRP $(0.5 \mu \mathrm{g} /$ $\mathrm{ml}$ ) and then washed again. For IRS-2, membranes were incubated for $2 \mathrm{~h}$ with primary antibody, rabbit polyclonal IgG anti IRS-2 $(1.0 \mu \mathrm{g} / \mathrm{ml})$, washed, followed by incubation for $90 \mathrm{~min}$ with anti rabbit IgG-HRP $(0.5 \mu \mathrm{g} / \mathrm{ml})$ and then washed again. Antigen-antibody complexes were visualized using the NEN Western blot Chemiluminescence Reagent Plus system (Perkin Elmer, Boston, MA, USA). For PI3K and IR $\beta$ subunit, membranes were exposed for $1 \mathrm{~min}$ while for IRS-1 and IRS-2 membranes 
were exposed for $2 \mathrm{~min}$ on the Kodak Image Station 440cf. Images were captured and transferred to the Kodak 1D Image Analysis software for further analysis.

\section{Reagents}

Hank's solution was used for the islet isolation. The perifusion medium consisted of $115 \mathrm{mM} \mathrm{NaCl}, 5 \mathrm{mM}$ $\mathrm{KCl}, 2 \cdot 2 \mathrm{mM} \mathrm{CaCl}, 1 \mathrm{mM} \mathrm{MgCl}, 24 \mathrm{mM} \mathrm{NaHCO}$ and $0 \cdot 17 \mathrm{~g} / \mathrm{dl}$ BSA. The ${ }^{125}$ I-labeled insulin for the insulin assay was purchased from New England Nuclear. BSA (RIA grade), glucose, carbachol, $\alpha$-KIC, wortmannin, LY294002 and the salts used to make the Hank's solution and perifusion medium were purchased from Sigma ( $\mathrm{St}$ Louis, MO, USA). Forskolin was obtained from Calbiochem (La Jolla, CA, USA). Nitrendipine was the gift of A Scriabine of the Miles Institute for Preclinical Pharmacology (Elkhart, IN, USA). Rat insulin standard (lot no. 615-ZS-157) was the generous gift of Dr Gerald Gold, Eli Lilly Co. (Indianapolis, IN, USA). Collagenase (Type P) was obtained from Boehringer Mannheim Biochemicals (Indianapolis, IN, USA). Anti rabbit IgG, anti $\beta$-subunit of the IR and anti IRS-1 were obtained from Santa Cruz Biotechnology, Inc, Santa Cruz, CA, USA. Anti IRS-2, anti PI3-K and the 3T3 cell lysates (positive controls for the IR, IRS-1, IRS-2 and PI3K) were obtained from Upstate Biotechnology, Lake Placid, NY, USA.

\section{Statistics}

Statistical significance was determined using the Student's $t$-test for unpaired data or analysis of variance in conjunction with the Newman-Keuls test for unpaired data. A $P$ value $\leq 0.05$ was taken as significant. Values presented in the figures and Results represent means \pm S.E. of at least three observations.

\section{Results}

\section{Responses of rat or mouse islets to $10 \mathrm{mM}$ glucose}

As shown in Fig. 1, rat islets respond to sustained $10 \mathrm{mM}$ glucose stimulation with a brisk biphasic insulin secretory response characterized by a large and rising second phase response. In the presence of $3 \mathrm{mM}$ glucose, prestimulatory release rates of $50 \pm 6 \mathrm{pg}$ /islet per min were measured. In response to $10 \mathrm{mM}$ glucose, peak first phase release rates averaged $93 \pm 14 \mathrm{pg} /$ islet per min. Secretion rates rose sharply as the perifusion progressed and 40,50 or $60 \mathrm{~min}$ after the onset of stimulation averaged $603 \pm 11,560 \pm 34$ or $554 \pm 25 \mathrm{pg}$ /islet per min respectively $(n=3)$. If one takes into account the steady decline in release rates from rat islets maintained at $3 \mathrm{mM}$ glucose alone for $90 \mathrm{~min}$ $(29 \pm 3 \mathrm{pg}$ /islet per $\min (n=3)$, results not shown), an approximately 15 - to 20 -fold increase in second phase

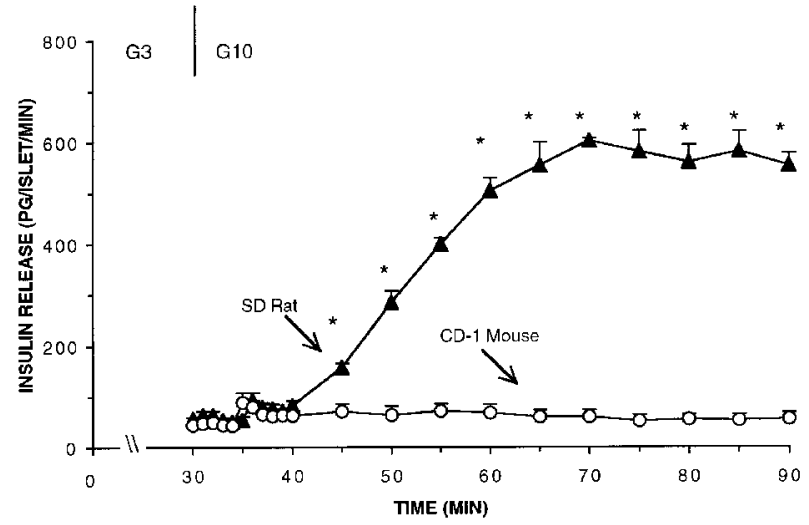

Figure 1 Glucose-induced release from perifused rat and mouse islets: studies with $10 \mathrm{mM}$ glucose. Groups of $14-18$ rat $(\boldsymbol{\Lambda}, n=3)$ or mouse $(\bigcirc, n=7)$ islets were isolated and perifused. For the initial $30 \mathrm{~min}$ the islets were maintained with $3 \mathrm{mM}$ glucose (G3) to establish basal and stable insulin secretory rates. Islets were then perifused (indicated by the vertical line) for $60 \mathrm{~min}$ with $10 \mathrm{mM}$ glucose (G10). Mean values \pm S.E. are given. The asterisks indicate a significant $(P<0 \cdot 05)$ difference between release values at these time-points. This and subsequent perifusion figures have not been corrected for the dead space in the perifusion apparatus, $2.5 \mathrm{ml}$ or $2.5 \mathrm{~min}$ with a flow rate of $1 \mathrm{ml} / \mathrm{min}$.

response to $10 \mathrm{mM}$ glucose stimulation was noted. This increment in glucose responsiveness compares favorably with that observed in studies using the perfused pancreas preparation (Gerich et al. 1974, Pagliara et al. 1974, Grill et al. 1978, O'Conner et al. 1980).

In response to $10 \mathrm{mM}$ glucose stimulation, peak first phase release rates from mouse islets averaged $89 \pm 18 \mathrm{pg} /$ islet per $\min (n=7)$ (Fig. 1), a value similar to that observed from rat islets in response to the hexose. However, at a time when release rates from rat islets were increased about 15- to 20-fold, the response from mouse islets was minimal. For example 40, 50 or $60 \mathrm{~min}$ after the onset of $10 \mathrm{mM}$ glucose stimulation release rates from mouse islets averaged $60 \pm 13,56 \pm 10$ or $56 \pm 13 \mathrm{pg}$ /islet per min respectively. Compared with release rates of $27 \pm 4 \mathrm{pg}$ /islet per $\min (n=3$, results not shown) from mouse islets maintained for $90 \mathrm{~min}$ at $3 \mathrm{mM}$ glucose, an approximately twofold increase in release rates was observed. This lack of response cannot be ascribed to insulin deficiency since exposure of these same islets to $20 \mathrm{mM}$ glucose plus $10 \mu \mathrm{M}$ carbachol was accompanied by a dramatic sustained increase in insulin release. For example, 15-20 min after the onset of $20 \mathrm{mM}$ glucose plus $10 \mu \mathrm{M}$ carbachol stimulation release rates increased to $671 \pm 85$ pg/islet per min (Fig. 2).

\section{Mouse islet responses to wortmannin}

Mouse islet responses to the PI3K inhibitor wortmannin were investigated next. The concentration $(50 \mathrm{nM})$ of wortmannin employed in these studies has been shown 


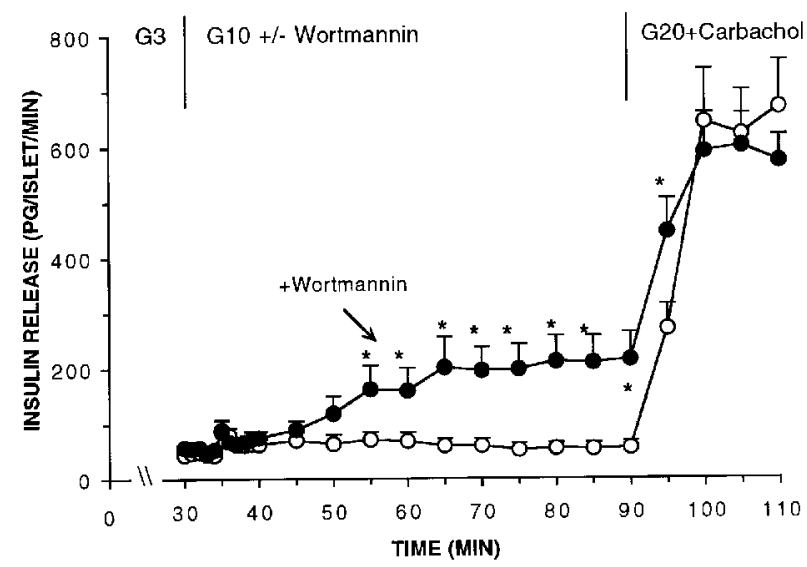

Figure 2 Effect of wortmannin on $10 \mathrm{mM}$ glucose-induced insulin release from mouse islets. Groups of mouse islets were perifused for $30 \mathrm{~min}$ with $3 \mathrm{mM}$ glucose and for an additional $60 \mathrm{~min}$ with $10 \mathrm{mM}$ glucose alone $(O, n=7$, these are the same mouse islet data as presented in Fig. 1) or in the additional presence of $50 \mathrm{nM}$ wortmannin $(\bullet, n=6)$. For the final $20 \mathrm{~min}$ of the perifusion both groups of islets were stimulated with $20 \mathrm{mM}$ glucose plus $10 \mu \mathrm{M}$ carbachol. Mean values \pm S.E. are given. The asterisks indicate significance $(P<0.05)$ between release rates measured in the presence or absence of wortmannin at these time-points.

previously by us to stimulate glucose-induced secretion about threefold (Zawalich \& Zawalich 2000). Studies by several groups using rat islets, $\beta$ TC3 or MIN6 cells have demonstrated that this level of wortmannin significantly inhibits PI3K activity between 60 and 90\% (Hagiwara et al. 1995, Gao et al. 1996). The results are presented in Fig. 2. The addition of the fungal metabolite markedly enhanced the responses of CD-1 mouse islets to $10 \mathrm{mM}$ glucose, particularly as the perifusion progressed. For example, release rates from islets stimulated with $10 \mathrm{mM}$ glucose alone averaged $60 \pm 13,56 \pm 10$ or $56 \pm 13 \mathrm{pg} /$ islet per min 40, 50 or $60 \mathrm{~min}$ after the onset of $10 \mathrm{mM}$ glucose stimulation respectively. The responses in the presence of $50 \mathrm{nM}$ wortmannin averaged $195 \pm 43$, $211 \pm 47$ or $215 \pm 49 \mathrm{pg} /$ islet per $\min (n=6)$ respectively, with all values being significantly $(P<0 \cdot 05)$ greater than control responses.

In response to $20 \mathrm{mM}$ glucose stimulation alone (Fig. $3)$, peak first phase release rates averaged $121 \pm 15 \mathrm{pg} /$ islet per min $(n=12)$. Sixty minutes after the onset of stimulation release rates averaged $70 \pm 12 \mathrm{pg}$ /islet per min. The inclusion of $50 \mathrm{nM}$ wortmannin had no significant effect on peak first phase release rates $(150 \pm 11 \mathrm{pg}$ /islet per min, $n=6)$. However, second phase secretory responses were significantly increased (Fig. 3). Stimulating both groups of islets with $20 \mathrm{mM}$ glucose plus $10 \mu \mathrm{M}$ carbachol for the final $20 \mathrm{~min}$ of the perifusion resulted in comparable rates of secretion.

Additional studies were conducted with mouse islets pretreated with $50 \mathrm{nM}$ wortmannin during the 30-min perifusion with $3 \mathrm{mM}$ glucose. In this case, the potentiat-

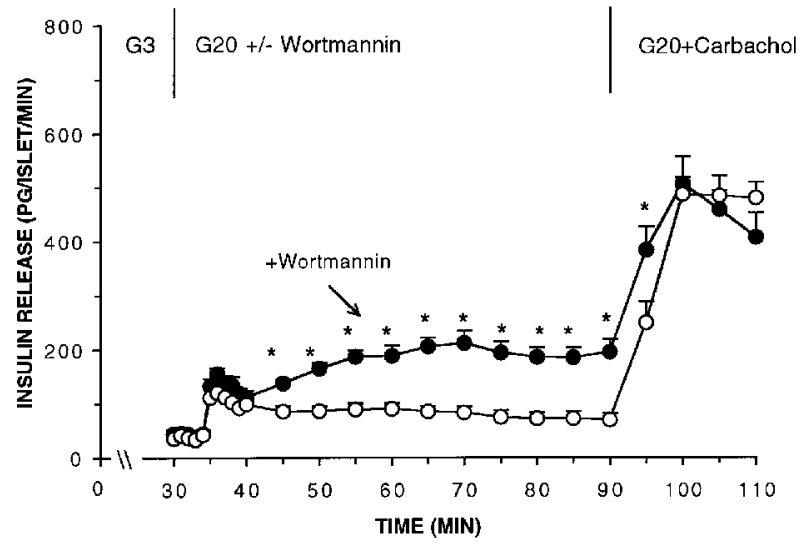

Figure 3 Effect of wortmannin on $20 \mathrm{mM}$ glucose-induced insulin release. Groups of mouse islets were perifused for $30 \mathrm{~min}$ with $3 \mathrm{mM}$ glucose and for an additional $60 \mathrm{~min}$ with $20 \mathrm{mM}$ glucose alone $(\bigcirc, n=12)$ or in the additional presence of $50 \mathrm{nM}$ wortmannin $(\bullet, n=6)$. For the final $20 \mathrm{~min}$ of the perifusion both groups of islets were stimulated with $20 \mathrm{mM}$ glucose plus $10 \mu \mathrm{M}$ carbachol. Mean values \pm S.E. are given. The asterisks indicate significance $(P<0 \cdot 05)$ between release rates measured in the presence or absence of wortmannin. At least four experiments were conducted under each condition.

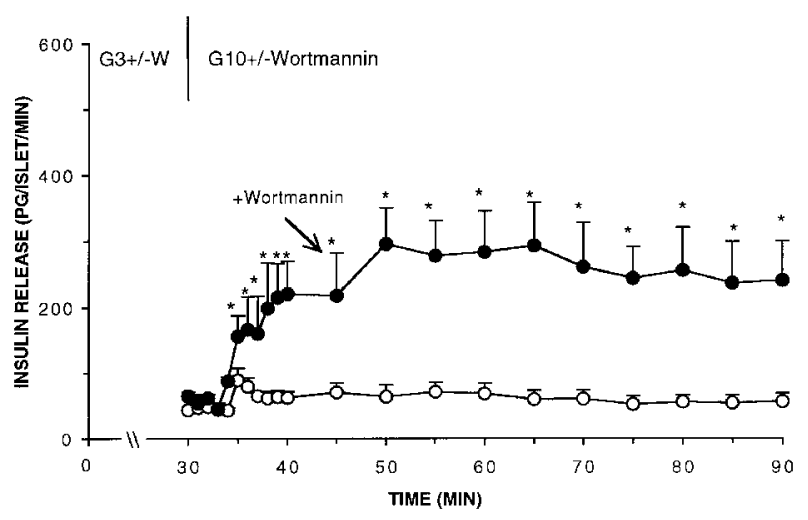

Figure 4 Pretreating CD-1 mouse islets with wortmannin accelerates potentiated responses to $10 \mathrm{mM}$ glucose. One group of mouse islets was perifused for $30 \mathrm{~min}$ with $3 \mathrm{mM}$ glucose and for an additional $60 \mathrm{~min}$ with $10 \mathrm{mM}$ glucose alone $(O, n=7$, these are the same mouse islet data as presented in Fig. 1). The second group $(\bullet, n=4)$ was similarly treated except that $50 \mathrm{nM}$ wortmannin $(\mathrm{W})$ was included during the entire perifusion. Mean values \pm S.E. are given. The asterisks indicate significance $(P<0 \cdot 05)$ between release rates measured in the presence or absence of wortmannin at these time-points.

ing effects of the fungal metabolite on secretion in response to $10 \mathrm{mM}$ glucose stimulation were evident at earlier times (Fig. 4).

\section{Effects of nitrendipine on wortmannin-potentiated secretion}

Blocking calcium influx into the $\beta$-cell abolishes glucoseinduced insulin secretion (Henquin et al. 1982). In the next series of experiments, islets were perifused and 


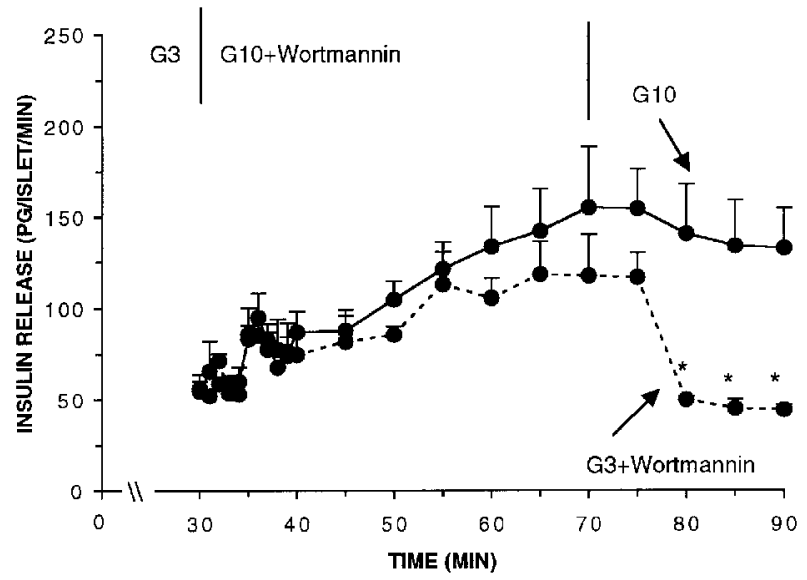

Figure 5 Examining the reversibility of wortmannin's effect on glucose-induced release. Two groups of mouse islets were studied. They were both perifused for $30 \mathrm{~min}$ with $3 \mathrm{mM}$ glucose and for an additional 40 min with $10 \mathrm{mM}$ glucose plus $50 \mathrm{nM}$ wortmannin (indicated by the vertical line). For the final $20 \mathrm{~min}$, one group was perifused $10 \mathrm{mM}$ glucose alone (solid line, $n=4$ ) while the second group was perifused with $3 \mathrm{mM}$ glucose plus $50 \mathrm{nM}$ wortmannin (broken line, $n=4$ ). Note the rapid decline in secretion when the glucose level was lowered to $3 \mathrm{mM}$ but not when wortmannin was omitted from the medium in the continued presence of $10 \mathrm{mM}$ glucose. Mean values \pm S.E. are given. The asterisks indicate a significant $(P<0 \cdot 05)$ difference between release values at this time.

stimulated with the combination of $10 \mathrm{mM}$ glucose, $50 \mathrm{nM}$ wortmannin plus $500 \mathrm{nM}$ of the calcium channel influx inhibitor nitrendipine. The inclusion of the calcium channel antagonist blocked insulin secretion to the combination of $10 \mathrm{mM}$ glucose plus wortmannin. For example, in the absence of nitrendipine, release rates in response to glucose plus wortmannin averaged $195 \pm 43$, $211 \pm 47$ or $215 \pm 49 \mathrm{pg} /$ islet per $\min (n=6) 40,50$ or $60 \mathrm{~min}$ after the onset of stimulation respectively (Fig. 2). In the additional presence of nitrendipine, release rates at these times averaged $33 \pm 5,41 \pm 7$ or $35 \pm 2 \mathrm{pg}$ /islet per $\min (n=3)$ respectively (results not shown).

\section{Reversibility of wortmannin}

Mouse islets were stimulated for $40 \mathrm{~min}$ with $10 \mathrm{mM}$ glucose plus $50 \mathrm{nM}$ wortmannin (Fig. 5). Consistent with previous findings, release rates increased. Forty minutes after the onset of stimulation, wortmannin was omitted from the perifusion medium (the glucose concentration was clamped at $10 \mathrm{mM}$ ) or the glucose level was lowered to $3 \mathrm{mM}$ (the wortmannin concentration was clamped at $50 \mathrm{nM}$ ). Increased rates of insulin release persisted in spite of the removal of the fungal metabolite from $10 \mathrm{mM}$ glucose-containing perifusion medium. However, in spite of the continued presence of $50 \mathrm{nM}$ wortmannin, release rates abruptly subsided to prestimulatory values when the glucose level was lowered to $3 \mathrm{mM}$ (Fig. 5).
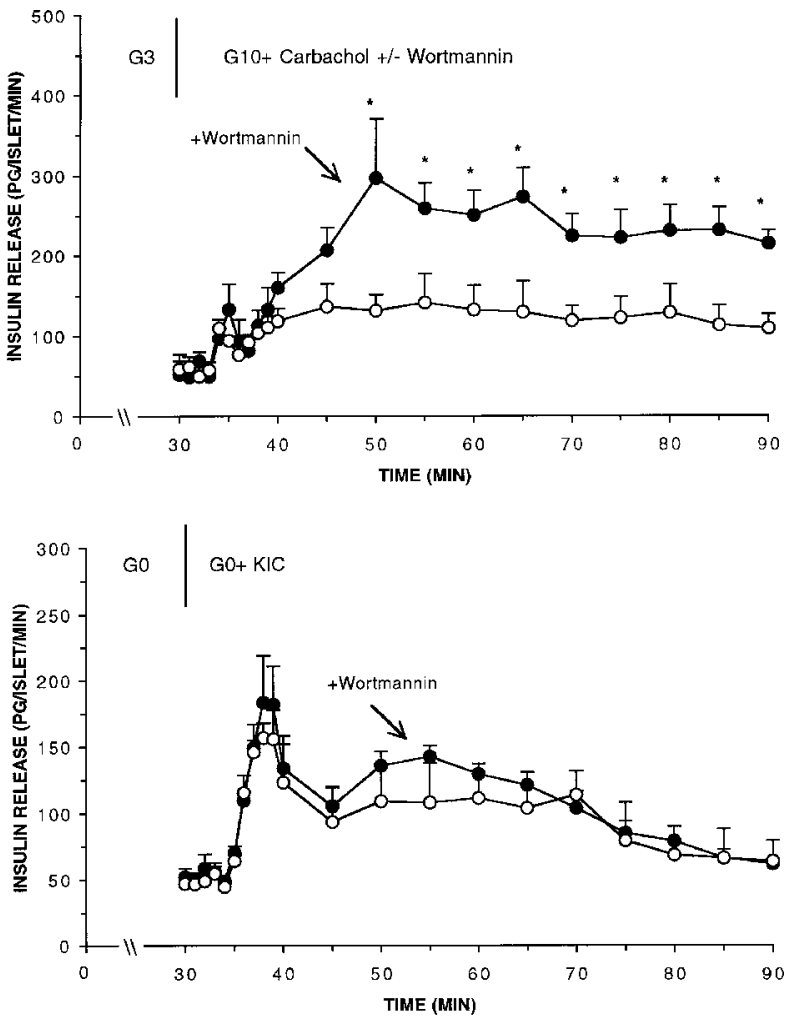

Figure 6 Wortmannin amplifies release in response to glucose plus carbachol but not to $\alpha$-ketoisocaproate (KIC). Groups of mouse islets were perifused for $30 \mathrm{~min}$ with $3 \mathrm{mM}$ glucose. (Top) For the next $60 \mathrm{~min}$ (onset indicated by vertical line) islets were stimulated with $10 \mathrm{mM}$ glucose plus $1 \mu \mathrm{M}$ carbachol $(\bigcirc, n=4)$ or $10 \mathrm{mM}$ glucose plus $1 \mu \mathrm{M}$ carbachol plus $50 \mathrm{nM}$ wortmannin ( $n=4$ ). (Bottom) For the next 60 min islets were stimulated (indicated by vertical line) with $10 \mathrm{mM} \mathrm{KIC}$ alone $(O, n=5)$ or $10 \mathrm{mM} \mathrm{KIC}$ plus $50 \mathrm{nM}$ wortmannin $(\bullet, n=5)$. Mean values \pm S.E. are given. The asterisks indicate a significant $(P<0 \cdot 05)$ difference between release values at these time-points.

\section{Specificity of wortmannin}

Wortmannin amplified insulin release from mouse islets stimulated with $10 \mathrm{mM}$ glucose plus $1 \mu \mathrm{M}$ carbachol (Fig. 6 , top). However, when used at a stimulatory concentration approximately equipotent to $10 \mathrm{mM}$ glucose, $50 \mathrm{nM}$ wortmannin had no effect on release stimulated by $10 \mathrm{mM} \alpha$-KIC (Fig. 6, bottom).

Effects of LY294002 on $10 \mathrm{mM}$ glucose-induced release from mouse islets

The inhibitory effects of wortmannin on PI3K activity can be duplicated by a structurally distinct compound, LY294002 (Vlahos et al. 1994). If the amplifying effects of wortmannin on $10 \mathrm{mM}$ glucose-induced release from mouse islets is due to PI3K inhibition, then it might be predicted that LY294002 should have a similar 


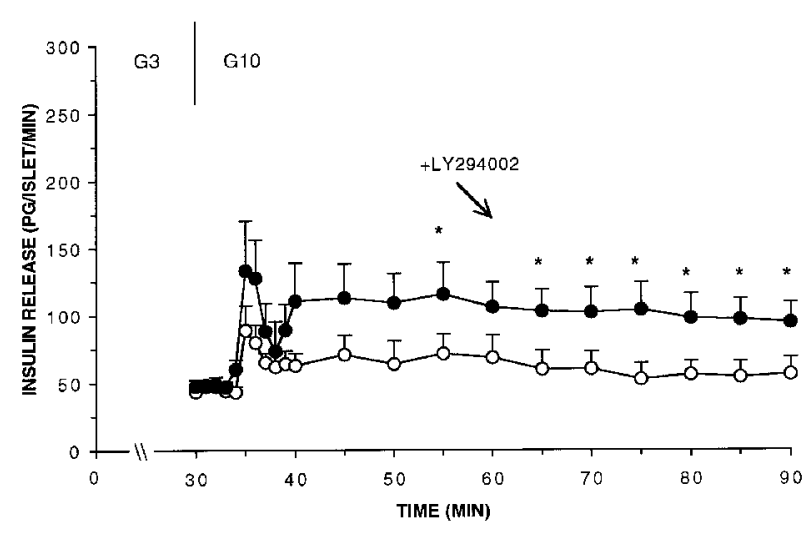

Figure 7 LY294002 potentiates $10 \mathrm{mM}$ glucose-induced insulin secretion. Groups of 14-18 mouse islets were isolated and perifused. For the initial 30 min all islets were maintained with $3 \mathrm{mM}$ glucose to establish basal and stable insulin secretory rates. Islets were then perifused (indicated by the vertical line) for $60 \mathrm{~min}$ with $10 \mathrm{mM}$ glucose alone $(O, n=7$, these are the same data as in Fig. 2) or $10 \mathrm{mM}$ glucose plus $10 \mu \mathrm{M}$ LY294002 ( $n=5)$. Mean values \pm S.E. are given. The asterisks indicate a significant $(P<0.05)$ difference between release rates at this time.

potentiating effect. This was investigated next. LY294002 $(10 \mu \mathrm{M})$ potentiated $10 \mathrm{mM}$ glucose-induced release (Fig. 7). The stimulatory effect of LY294002 was smaller than that observed with $50 \mathrm{nM}$ wortmannin (compare Figs 2 and 7).

\section{Effects of wortmannin on release from ob/ob mouse islets}

A variety of mouse models have been employed to probe the nature of the insulin signaling systems that regulate glucose homeostasis. Prominent among these is the ob/ob mouse model of hyperinsulinemia, insulin resistance and obesity. It has been reported that signaling via the PI3K pathway is markedly impaired in vivo in these animals, a biochemical lesion thought to play an important role in their insulin resistance (Folli et al. 1993, Kerouz et al. 1997). The impact of wortmannin on release from ob/ob mouse islets or their lean littermates was determined. Like islets isolated from CD-1 mice, islets isolated from lean C57BL donors were sensitive to the augmenting effect of $50 \mathrm{nM}$ wortmannin (Fig. 8, top). For example, while insulin release rates from control islets stimulated with $10 \mathrm{mM}$ glucose alone averaged $44 \pm 5, \quad 36 \pm 3$ or $27 \pm 4 \mathrm{pg} /$ islet per $\min (n=3) 40,50$ or $60 \mathrm{~min}$ after the onset of stimulation, the inclusion of $50 \mathrm{nM}$ wortmannin significantly $(P<0 \cdot 05)$ increased the responses at these times to $85 \pm 10,94 \pm 12$ or $99 \pm 10 \mathrm{pg}$ /islet per $\min$ $(n=4)$ respectively.

We next examined the actions of wortmannin on $10 \mathrm{mM}$ glucose-induced insulin release rates from ob/ob mouse islets. As previously reported (Chen et al. 1993, Zawalich \& Zawalich 1996b, Chen \& Romsos 1997), islets isolated from these animals were significantly more
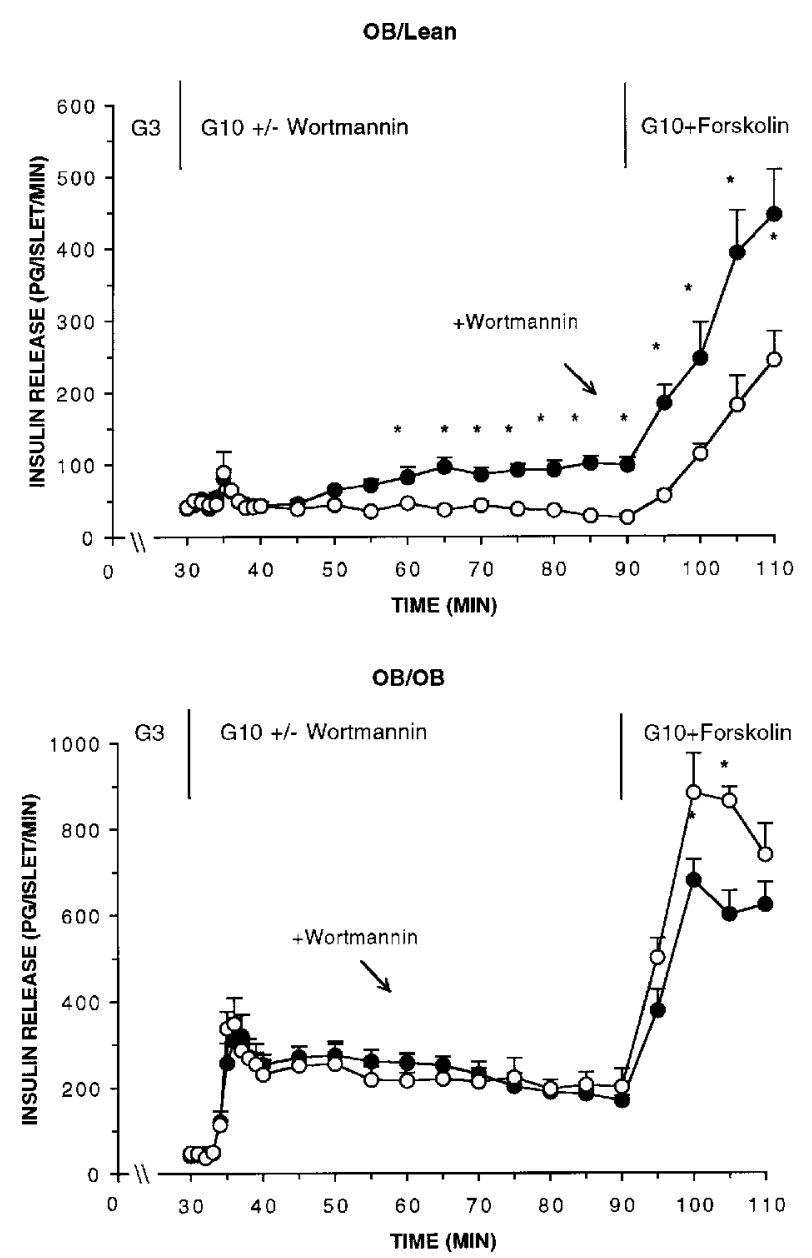

Figure 8 Effect of wortmannin on $10 \mathrm{mM}$ glucose-induced insulin release from islets of lean or ob/ob mice. (Top) Two groups of 14-18 islets were isolated from lean littermates of ob/ob mice and perifused for $30 \mathrm{~min}$ with $3 \mathrm{mM}$ glucose. One group $(\bigcirc$, $n=4$ ) was then stimulated with $10 \mathrm{mM}$ glucose alone for $60 \mathrm{~min}$. The second group $(\bullet, n=4)$ was stimulated with $10 \mathrm{mM}$ glucose plus $50 \mathrm{nM}$ wortmannin for $60 \mathrm{~min}$. For the final $20 \mathrm{~min}$ both groups were perifused with $10 \mathrm{mM}$ glucose plus $5 \mu \mathrm{M}$ forskolin. Mean values \pm S.E. are given. The asterisks indicate a significant $(P<0.05)$ difference between release values at this time. (Bottom) Two groups of 14-18 islets were isolated from ob/ob mice and perifused for $30 \mathrm{~min}$ with $3 \mathrm{mM}$ glucose. One group $(\bigcirc, n=5)$ was then stimulated with $10 \mathrm{mM}$ glucose alone for $60 \mathrm{~min}$. The second group $(\bullet, n=5)$ was stimulated with $10 \mathrm{mM}$ glucose plus $50 \mathrm{nM}$ wortmannin. For the final $20 \mathrm{~min}$ both groups were perifused with $10 \mathrm{mM}$ glucose plus $5 \mu \mathrm{M}$ forskolin. Mean values \pm S.E. are given. The asterisks indicate a significant $(P<0 \cdot 05)$ difference between release values at this time. Note the change in scale between top and bottom panels.

responsive to $10 \mathrm{mM}$ glucose than islets from their lean counterparts (compare open circles in Fig. 8 (top) with open circles in Fig. 8 (bottom)). Both phases of release were amplified from ob/ob mouse islets although the kinetics of the response, a spike of first phase insulin 

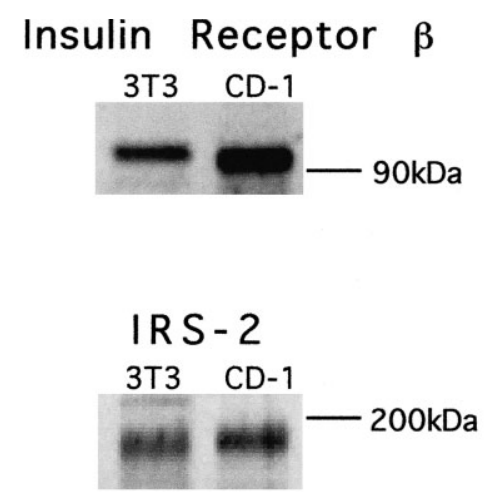
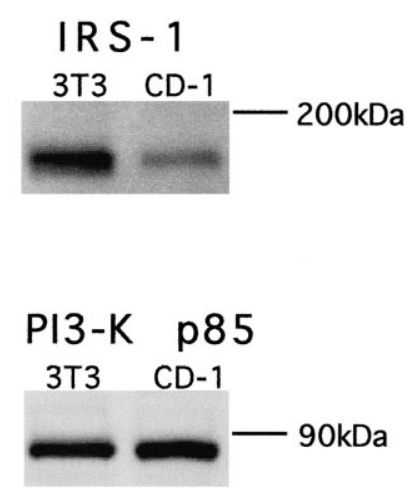

Figure 9 CD-1 mouse islets express insulin receptor (IR), IR substrate (IRS)-1, IRS-2 and phosphatidylinositol 3-kinase (PI3K). Groups of CD-1 mouse islets were sonicated, Western blotted $(30 \mu \mathrm{g}$ protein/lane) and probed for the presence of insulin signaling compounds. The IR $\beta$ subunit was detected at $93 \mathrm{kDa}$, IRS- 1 at $175 \mathrm{kDa}$, IRS-2 at $185 \mathrm{kDa}$ and the PI3K p85 subunit at $85 \mathrm{kDa}$. Control cell lysates from $3 \mathrm{~T} 3$ cells $(20 \mu \mathrm{g} / \mathrm{lane}$, left lane in all blots) were similarly treated. Two to three separate experiments were performed under each condition and a representative blot is shown.

secretion followed by a sustained but flat second phase response, were similar to those of lean islets. When stimulated with $10 \mathrm{mM}$ glucose in the presence of $50 \mathrm{nM}$ wortmannin, islets from $\mathrm{ob} / \mathrm{ob}$ mice, in contrast to lean CD-1 mouse islets or lean C57BL mouse islets, were immune to the potentiating effect of the fungal metabolite. At no time-point during the perifusion was any amplifying effect observed.

\section{Western blot analyses}

The concept that wortmannin exerts its effects on $\beta$-cell responses via inhibition of PI3K signaling would be supported by the demonstration that insulin signaling components are present in our islet preparations. To this end, CD-1 mouse islet homogenates were Western blotted and probed for the IR, IRS-1, IRS-2 and PI3K. As shown in Fig. 9, when compared with control cell lysates, strong bands corresponding to the IR, IRS -2 and PI3K were detected in CD-1 mouse islets while a considerably lesser signal was detected for IRS-1.

\section{Discussion}

We reported previously that insulin secretion from rat islets in response to $8 \mathrm{mM}$ glucose stimulation was dramatically potentiated by $50 \mathrm{nM}$ wortmannin, a fungal metabolite that potently inhibits PI3K at the level employed in these studies (Okada et al. 1994, Hagiwara et al. 1995, Gao et al. 1996). This effect on insulin release led us to suggest that PI3K activity in $\beta$-cells may provide a communications link between islets and peripheral tissues. In this context we speculated that, as peripheral tissues become resistant to circulating insulin as a consequence of reduced signaling via the PI3K pathway (Kim et al. 1999, Cusi et al. 2000), the same biochemical perturbation at the level of the $\beta$-cell evokes a linked and compensatory insulin secretory response from these cells. We also predicted that wortmannin should be less effective in stimulating release from islets of Zucker fatty rats, a model of hyperglycemia, hyperinsulinemia and insulin resistance in which in vivo reductions in PI3K activity have been demonstrated (Anai et al. 1998). This prediction was confirmed (Zawalich \& Zawalich 2000).

These initial studies using rat islets to study the interrelationships between PI3K inhibition by wortmannin and the secretion of insulin from $\beta$-cells prompted us to consider similar experiments with freshly isolated and perifused mouse islets. This was done for several reasons. First, since mouse islet responses to glucose stimulation deviate from rat islets in several major ways (Berglund 1987, Zawalich et al. 1995b), we considered it prudent to establish whether this anomalous behavior to glucose might be extended to wortmannin as well. Secondly, studies using HIT cells (Straub \& Sharp 1996) treated with wortmannin have suggested that PI3K activation may play a stimulatory role in the insulin secretory process, while studies with cultured neonatal rat monolayer pancreatic islets (Zhao et al. 1998) suggest that PI3K activation mediates leptin-induced inhibition of secretion. However, in terms of their sensitivity to glucose stimulation, the preparations employed in these previous studies deviate from normal islets. Thirdly, transgenic and knockout mice are being increasingly employed to probe the contribution of insulin signaling pathway lesions to the regulation of glucose homeostasis (Araki et al. 1994, Brüning et al. 1997, Kulkarni et al. 1999a). Fourthly, disruption of insulin signaling often culminates in hyperinsulinemia, a result that might be predicted if insulin functions normally to 
restrain insulin output from them (Araki et al. 1994, Tamemoto et al. 1994, Brüning et al. 1997).

Due in part to the small amounts of islet tissue available for investigation and the large numbers required to accurately measure PI3K activity (Gao et al. 1996), we did not directly measure the inhibition of PI3K by wortmannin. However, the wortmannin levels employed in these experiments are exactly the same as those used to inhibit the enzyme in a large number of preparations including $\beta$-cells (Acaro \& Wymann 1993, Gao et al. 1994, Okada et al. 1994, Hagiwara et al. 1995, Hausdorff et al. 1999). Islets were collagenase isolated and immediately perifused to assess the kinetics and amplitude of their insulin secretory responses to glucose. Islets were not cultured prior to study. This approach was employed for several reasons. First, statically incubated islets may not be optimal for this type of analysis. This preparation yields no information on the dynamics of release. Secondly, statically incubated islets are vulnerable to the effects of products that accumulate in the medium and that appear to negatively influence insulin release from them (Loreti et al. 1974, Ammon \& Verspohl 1976, Easom et al. 1997). Thirdly, short-term culture, of rat islets at least, diminishes their secretory responses to glucose stimulation (Malaisse-Lagae et al. 1987, Metz 1988, Zawalich et al. 1995a) and by using freshly studied islets we avoided the potential introduction of any artifacts induced by culturing.

These studies with mouse islets parallel those we previously reported using rat islets (Zawalich \& Zawalich 2000) and their conduct was motivated by previous reports demonstrating differences to glucose stimulation between these two species (Berglund 1980, Ma et al. 1995, Zawalich et al. 1995b). We first confirmed that these differences to glucose stimulation exist under the conditions employed in these experiments.

The next set of experiments was conducted with wortmannin. A concentration of $50 \mathrm{nM}$ was employed for these studies since, at this level, maximal effects on glucose-induced release from rat islets were noted previously (Zawalich \& Zawalich 2000). While profound differences in their sensitivity to glucose stimulation exist, mouse islets like rat islets were sensitive to the potentiating effects of wortmannin on glucose-induced release. In response to $10 \mathrm{mM}$ glucose plus wortmannin, secretion was maximally increased by three- to fourfold above release rates observed in the presence of $10 \mathrm{mM}$ glucose alone. No effect of wortmannin on release was observed if the glucose level was maintained at $3 \mathrm{mM}$. In addition, while the augmenting effect of wortmannin on $10 \mathrm{mM}$ glucose persisted even after its removal from the medium, lowering the glucose level to $3 \mathrm{mM}$ resulted in a rapid abatement of release. If wortmannin specifically inhibits PI3K at the level employed, these findings suggest that PI3K activation restrains the impact of a glucose-derived metabolic signal on the secretory process.
Several other aspects of wortmannin's effects on islet responses were investigated. First, the effects of the fungal metabolite are dependent on calcium influx, since the calcium channel antagonist nitrendipine abolished release to the hexose plus wortmannin. This, and its glucose dependency, would seem to preclude non-specific $\beta$-cell damage and the subsequent leakage of insulin into the perifusion medium as the cause of wortmannin's effects. Secondly, wortmannin further potentiated the secretory responses of mouse islets to stimulation by the combination of glucose plus carbachol. This combination of agonists was selected since meal-induced insulin release appears to be regulated, at least in part, by both glucose and vagally derived cholinergic signals (Loubatieres-Mariani et al. 1973, Louis-Sylvestre 1976, 1978, Zawalich et al. 1989a). Finally, and potentially important with regards to its potential mechanism of action, is the finding that wortmannin had no effect on $\alpha$-KIC-induced secretion. This deamination product of leucine metabolism is exclusively metabolized within the mitochondria (Panten et al. 1974, Panten 1975).

We duplicated the potentiating effects of PI3K inhibition on $\beta$-cell responses to glucose by using a structurally distinct inhibitor of the enzyme, LY294002 (Vlahos et al. 1994). This finding lends further credence to the concept that inhibition of PI3K plays a role, at least in part, in the amplified secretory responses observed from mouse islets to $10 \mathrm{mM}$ glucose stimulation.

We next attempted to establish the potential in vivo physiologic and pathophysiologic relevance of these in vitro observations. For this we employed islets isolated from $\mathrm{ob} / \mathrm{ob}$ mice. These animals are characterized by obesity, hyperglycemia, insulin resistance and hyperinsulinemia (Kahn 1980). Pertinent to the next series of experiments using islets isolated from them is the observation that in vivo signaling via PI3K is also impaired in liver and muscle from these animals (Kerouz et al. 1997) and that islets isolated from ob/ob mice are resistant to the negative feedback effect that insulin exerts on its own secretion (Loreti et al. 1974). Based on previous studies (Loreti et al. 1974, Soll et al. 1974, Kerouz et al. 1997), we theorized that the reduction in PI3K activity demonstrated in liver and muscle might not be uniquely confined to these tissues but might also be present in ob/ob islets. If this is an accurate portrayal of in vivo biochemical events, then it might be predicted that islets isolated from ob/ob mice, in which PI3K activity may be already reduced, would be less sensitive to the potentiating effect of PI3K inhibition by wortmannin. The next experiments focused on this issue.

As a precondition to the conduct of these studies, it was imperative initially to address three important issues. First, we had to establish that islets from lean littermates of $\mathrm{ob} / \mathrm{ob}$ mice, like CD-1 mice, are relatively insensitive to $10 \mathrm{mM}$ glucose stimulation alone. Secondly, we had to establish that islets from lean C57BL mice are sensitive 
to the potentiating effects of wortmannin. Thirdly, we had to confirm that islets from ob/ob mice are hyperresponsive to glucose stimulation in vitro as they are in vivo. The results of these experiments are as follows: (1) when stimulated with $10 \mathrm{mM}$ glucose alone, and in contrast to rat islet responses but similar to that observed with islets isolated from CD-1 mice, lean C57BL mice are minimally responsive to $10 \mathrm{mM}$ glucose stimulation; (2) however, wortmannin potentiated $10 \mathrm{mM}$ glucose-induced secretion from this strain of mice as it does in CD-1 mice and rats; (3) confirming previous studies (Chen et al. 1993, Zawalich \& Zawalich 1996b, Chen \& Romsos 1997), islets from ob/ob mice are hyper-responsive to glucose stimulation during a dynamic perifusion in vitro. The fulfillment of these three conditions led us to conduct studies using ob/ob islets stimulated with glucose plus wortmannin.

When stimulated with $10 \mathrm{mM}$ glucose plus $50 \mathrm{nM}$ wortmannin, a combination that results in a threefold potentiation of secretion from control CD-1 or C57BL mice, no amplifying effect on $10 \mathrm{mM}$ glucose-induced secretion was observed from ob/ob mouse islets. It thus appears that the reduced activity of PI3K documented to occur in vivo in several insulin-dependent tissues (Folli et al. 1993, Kerouz et al. 1997) may occur in their $\beta$-cells as well, is maintained during the islet isolation procedure, and is responsible, at least in part, for the augmented in vivo and in vitro secretory responses of $\mathrm{ob} / \mathrm{ob}$ mouse islets to glucose stimulation and also for ob/ob islet insensitivity to wortmannin. The findings presented here with wortmannin and a previous report demonstrating that islets from $\mathrm{ob} / \mathrm{ob}$ mice are resistant to the negative feedback effect that insulin exerts on its own secretion (Loreti et al. 1974) also suggest a common biochemical explanation: reduced $\beta$-cell PI3K activity. While other factors, including islet hypertrophy, have to be considered as contributing to this amplified secretory response to glucose, the fact that wortmannin sensitivity is abolished in these animals points to a potentially important role for disrupted PI3K activation.

Disruption of insulin signaling pathways has been reported in knockout mice with consistent effects on the $\beta$-cell. For example, Tamemoto et al. (1994) found significantly higher plasma insulin levels in mice with targeted disruption of IRS-1 gene when compared with control animals. Plasma glucose levels were comparable and thus could not account for the hyperinsulinemia. Similar findings were reported by Araki et al. (1994). Mice double heterozygous for null alleles in the IR and IRS-1 genes develop marked hyperinsulinemia despite no significant changes in plasma glucose concentrations from fed animals (Brüning et al. 1997). Mice with combined heterozygous null mutations in the IR, IRS-1 and/or IRS-2 are characterized by both fed and fasting hyperinsulinemia with little if any alteration in plasma glucose levels (Kido et al. 2000). While $\beta$-cell hyperplasia un- doubtedly contributes to hyperinsulinemia in these genetically altered mice, this effect is variable and does not always correlate with the degree of hyperinsulinemia (Brüning et al. 1997, Kido et al. 2000). Most recently, Eto et al. (2002) reported that islets isolated from mice deficient in the p85 regulatory subunit of PI3K exhibit augmented insulin secretory responses to glucose stimulation. These findings and the present studies suggest that a reduction in the negative feedback effect that insulin exerts upon its own secretion from the $\beta$-cell (Iversen \& Miles 1971, Ammon \& Verspohl 1976, Liljenquist et al. 1978, Ammon et al. 1991) may play a role in their in vitro hypersensitivity to glucose and their in vivo development of hyperinsulinemia.

Several studies have examined the effects of $\beta$-cell specific alterations in the IR and IRS-1 (Kulkarni et al. $1999 a, b)$ on $\beta$-cell function. Tissue-specific knockout of the IR results in a reduction in glucose-stimulated insulin secretion in vivo. Arginine-induced release was unaffected (Kulkarni et al. 1999a). In contrast, both glucose- and arginine-induced release in vivo is impaired in IRS-1deficient mouse islets (Kulkarni et al. 1999b). After a 48-h culture period in Dulbecco's minimum essential medium (DMEM), impaired responses to glucose stimulation in batch-incubated islets isolated from IRS-1-deficient animals were also noted. For at least several reasons it is difficult to compare these findings with ours. First, our studies were acute in nature. Long-term reductions in insulin signaling might induce unique $\beta$-cell alterations not evident in short-term perifusion studies. Secondly, our islets were studied immediately after isolation. In rat islets, at least, short-term culturing results in profound reductions in $\beta$-cell function (Malaisse-Lagae et al. 1987, Metz 1988, Zawalich et al. 1995a). Whether similar changes occur in mouse islets cannot be excluded. Thirdly, our islets were studied during a dynamic perifusion. The excessive accumulation of potentially inhibitory factors is thus mitigated. Finally, our islets were stimulated in a KRB medium supplemented with one or at most two agonists for release. DMEM contains multiple amino acids with established cumulative effects on release that may influence the secretory responses to glucose. Their possible contribution to the secretory findings made has to be considered.

Based on islet volume and insulin secretory rates, it has been estimated that during maximal glucose stimulation insulin bathing the $\beta$-cell approaches $100-200 \mathrm{nM}$ (Zawalich et al. 1975), a level at least 1000-fold greater than systemic concentrations of the hormone (Del Prato et al. 1994, Robinson et al. 1998). Even under nonstimulatory conditions, the level of insulin bathing the $\beta$-cell must be far in excess of that bathing other insulinsensitive tissues such as liver, fat and muscle. For heuristic purposes at least, it might be proposed that these high levels of insulin exert a tonic negative feedback effect on insulin secretion via PI3K activation. This schema would explain why disruption of PI3K signaling by wortmannin 
amplifies glucose-induced insulin secretion. Failure of this normal negative feedback arrangement would be predicted to result in amplified secretory responses to glucose and may explain not only the hyperinsulinemia in obese animals such as the Zucker fatty rat and the ob/ob mouse but also the failure of wortmannin to further amplify secretion from islets of these animals (Zawalich \& Zawalich 2000). Yet to be established, however, is whether the disruption of PI3K signaling in $\beta$-cells of obese rats and mice is caused by hyperinsulinemia and/or hyperglycemia (Pillay et al. 1996).

To summarize, we have confirmed that CD-1 mouse islets contain the requisite insulin signaling proteins, IR, IRS-1, IRS-2 and PI3K, characterized in other insulindependent tissues. Secondly, islets isolated from several strains of control mice exhibit a profoundly reduced insulin secretory response to $10 \mathrm{mM}$ glucose stimulation when compared with rat islets studied under identical conditions. We have demonstrated that islets isolated from several strains of lean control mice, like islets isolated from lean rats, are sensitive to the potentiating effect of wortmannin. We have shown that islets isolated from ob/ob mice, an animal model characterized by insulin resistance, hyperinsulinemia, hyperglycemia and impaired PI3K activity in vivo, are insensitive to the amplifying effects of wortmannin in vitro. These mice are also less sensitive to the negative feedback effect that insulin exerts on its own secretion (Loreti et al. 1974). In this regard, the findings made with ob/ob mice are similar to our previous results obtained using perifused islets isolated from insulinresistant, hyperinsulinemic Zucker fatty rats (Zawalich \& Zawalich 2000). Thus, the in vivo status of the donor animals' insulin signaling pathways appears critical in determining in vitro islet sensitivity to wortmannin irrelevant of the animal model employed. Finally, these results suggest that the hyperinsulinemia resulting from insulin resistance may be a consequence of a similar biochemical lesion in liver, muscle, adipose and $\beta$-cells - a reduction in signaling via PI3K. This elegant control mechanism thus ensures that the release of insulin from the $\beta$-cell will be titrated to the degree of insulin resistance.

\section{Acknowledgements}

These studies were supported by NIH grant no. 41230 and by a grant from the American Diabetes Association. We thank John Cassidy for his constructive discussions and comments on our work.

\section{References}

Acaro A \& Wymann MP 1993 Wortmannin is a potent phosphatidylinositol 3-kinase inhibitor: the role of phosphatidylinositol 3,4,5trisphosphatein neutrophil responses. Biochemical Journal 296 297-301.
Albano JDM, Ekins RP, Maritz G \& Turner RC 1972 A sensitive, precise radioimmunoassay of serum insulin relying on charcoal separation of bound and free hormone moieties. Acta Endocrinologica $70487-509$.

Ammon HPT \& Verspohl E 1976 Pyridine nucleotides in pancreatic islets during inhibition of insulin release by exogenous insulin. Endocrinology 99 1469-1476.

Ammon HP, Reiber C \& Verspohl EJ 1991 Indirect evidence for short-loop negative feedback of insulin secretion in the rat. Journal of Endocrinology 128 27-34.

Anai M, Funaki M, Ogihara T, Kanda A, Onishi Y, Sakoda H, Inukai K, Nawano M, Fukushima Y, Yazaki Y, Kikuchi M, Oka Y \& Asano T 1998 Altered expression levels and impaired steps in the pathway to phosphatidylinositol 3-kinase activation via insulin receptor substrates 1 and 2 in Zucker fatty rats. Diabetes 47 13-23.

Araki E, Lipes MA, Patti M-E, Bruning JC, Haag B, Johnson RS \& Kahn CR 1994 Alternative pathway of insulin signalling in mice with targeted disruption of the IRS-1 gene. Nature 372 186-190.

Berglund O 1980 Different dynamics of insulin secretion in the perfused pancreas of the mouse and rat. Acta Endocrinologica 93 $54-60$.

Berglund O 1987 Lack of glucose-induced priming of insulin release in the perfused mouse pancreas. Journal of Endocrinology 114 185-189.

Best L \& Malaisse WJ 1983 Stimulation of phosphoinositide breakdown in pancreatic islets by glucose and carbamylcholine. Biochemical and Biophysical Research Communications 116 9-16.

Best L \& Malaisse WJ 1984 Nutrient and hormone-neurotransmitter stimuli induce hydrolysis of polyphosphoinositides in rat pancreatic islets. Endocrinology 115 1820-1831.

Brüning JC, Winnay J, Bonner-Weir S, Taylor SI, Accili D \& Kahn CR 1997 Development of a novel polygenic model of NIDDM in mice heterozygous for IR and IRS-1 null alleles. Cell 88 561-572.

Charles MA, Fanska R, Schmid FG, Forsham P \& Grodsky GM 1973 Adenosine $3^{\prime} 5^{\prime}$-monophosphate in pancreatic islets: glucoseinduced insulin release. Science 179 569-571.

Chen N-G \& Romsos DR 1997 Persistently enhanced sensitivity of pancreatic islets from $o b / o b$ mice to PKC-stimulated insulin secretion. American Journal of Physiology 272 E304-E311.

Chen N-G, Tassava TM \& Romsos DR 1993 Threshold for glucosestimulated insulin secretion in pancreatic islets of genetically obese (ob/ob) mice is abnormally low. Journal of Nutrition 123 1567-1574.

Curry DL 1986 Insulin content and insulinogenesis by the perfused rat pancreas: effects of long term glucose stimulation. Endocrinology 118 $170-175$.

Cusi K, Maezono K, Osman A, Pendergrass M, Patti ME, Pratipanawatr T, DeFronzo RA, Kahn CR \& Mandarino LJ 2000 Insulin resistance differentially affects the PI3-kinase- and MAP kinase-mediated signaling in human muscle. Journal of Clinical Investigation 105 311-320.

Del Prato S, Leonetti F, Simonson DC, Sheehan P, Matsuda M \& DeFronzo RA 1994 Effect of sustained physiologic hyperinsulinaemia and hyperglycaemia on insulin secretion and insulin sensitivity in man. Diabetologia 37 1025-1035.

Easom RA, Filler NR, Ings EM, Tarpley J \& Landt M 1997 Correlation of the activation of $\mathrm{Ca}^{2+} /$ calmodulin dependent protein kinase II with the initiation of insulin secretion from perifused pancreatic islets. Endocrinology 138 2359-2364.

Elahi D 1996 In praise of the hyperglycemic clamp: a method for assessment of beta-cell sensitivity and insulin resistance. Diabetes Care 19 278-286.

Eto K, Yamashita T, Tsubamoto Y, Terauchi Y, Hirose K, Kubota N, Yamahita S, Taka J, Satoh S, Sekihara H, Tobe K, Iino M, Noda M, Kimura S \& Kadowaki T 2002 Phosphatidylinositol 3-kinase suppresses glucose-stimulated insulin secretion by affecting post-cytosolic $\left[\mathrm{Ca}^{2+}\right]$ elevation signals. Diabetes $\mathbf{5 1} 87-97$. 
Folli F, Saad MJA, Backer JM \& Kahn CR 1993 Regulation of phosphatidyinositol 3-kinase activity in liver and muscle of animal models of insulin-resistant and insulin-deficient diabetes mellitus. Journal of Clinical Investigation 92 1787-1794.

Gao Z-Y, Gilon P \& Henquin J-C 1994 The role of protein kinase-C in signal transduction through vasopressin and acetylcholine receptors in pancreatic $\beta$-cells from normal mouse. Endocrinology 135 191-199.

Gao Z, Konrad RJ, Collins H, Matschinsky FM, Rothenberg PL \& Wolf BA 1996 Wortmannin inhibits insulin secretion in pancreatic islets and B-TC3 cells independent of its inhibition of phosphatidyinositol 3-kinase. Diabetes 45 854-862.

Gerich JE, Charles MA \& Grodsky GM 1974 Characterization of the effects of arginine and glucose on glucagon and insulin release from the perfused rat pancreas. Journal of Clinical Investigation $\mathbf{5 4}$ 833-841.

Grill V, Adamson U \& Cerasi E 1978 Immediate and time-dependent effects of glucose on insulin release from rat pancreatic tissue. Journal of Clinical Investigation 61 1034-1043.

Hagiwara S, Sakurai T, Tashiro F, Hashimoto Y, Matsuda Y, Nonomura Y \& Miyazaki J 1995 An inhibitory role for phosphatidylinositol 3-kinase in insulin secretion from pancreatic $\beta$ cell line MIN6. Biochemical and Biophysical Research Communications 214 51-59.

Harbeck MC, Louie DC, Howland J, Wolf BA \& Rothenberg PL 1996 Expression of insulin receptor mRNA and insulin receptor substrate 1 in pancreatic islet $\beta$-cells. Diabetes 45 711-717.

Hausdorff SF, Fingar DC, Moroika K, Garza LA, Whiteman EL, Summers SA \& Birnbaum MJ 1999 Identification of wortmanninsensitive targets in 3T3-L1 adipocytes. Journal of Biological Chemistry 272 24677-24684.

Henquin J-C \& Lambert A 1976 Bicarbonate modulation of glucoseinduced biphasic insulin release by rat islets. American Journal of Physiology 231 713-721.

Henquin JC, Charles S, Nenquin M, Mathot F \& Tamagawa T 1982 Diazoxide and D600 inhibition of insulin release. Distinct mechanisms explain the specificity for different stimuli. Diabetes $\mathbf{3 1}$ 776-783.

Iversen J \& Miles DW 1971 Evidence for a feedback inhibition of insulin on insulin secretion in the isolated, perfused canine pancreas. Diabetes 20 1-9.

Kahn CR 1980 Role of insulin receptors in insulin-resistant states. Metabolism 29 455-466.

Kerouz NJ, Horsch D, Pons S \& Kahn CR 1997 Differential regulation of insulin receptor substrates-1 and -2 (IRS-1 and IRS-2) and phosphatidylinositol 3-kinase isoforms in liver and muscle of the obese diabetic (ob/ob) mouse. Journal of Clinical Investigation 100 3164-3172.

Kido Y, Burks DJ, Withers D, Bruning J, Kahn CR, White MF \& Accili D 2000 Tissue-specific insulin resistance in mice with mutations in the insulin receptor, IRS-1, and IRS-2. Journal of Clinical Investigation 105 199-205.

Kim Y-B, Nikoulina SE, Ciaraldi TP, Henry RR \& Kahn BB 1999 Normal insulin-dependent activation of Akt/protein kinase B, with diminished activation of phosphoinositide 3-kinase, in muscle in type 2 diabetes. Journal of Clinical Investigation 104 733-741.

Kubota N, Tobe K, Terauchi Y, Eto K, Yamauchi T, Suzuki R, Tsubamoto Y, Komeda K, Nakano R, Miki H, Satoh S, Sekihara H, Sciacchitano S, Lesniak M, Aizawa S, Nagai R, Kimura S, Akanuma Y, Taylor SI \& Kadowaki T 2000 Disruption of insulin receptor substrate 2 causes Type 2 diabetes because of liver insulin resistance and lack of $\beta$-cell hyperplasia. Diabetes 49 1880-1889.

Kulkarni RN, Bruning JC, Winnay JN, Postic C, Magnuson MA \& Kahn CR 1999a Tissue-specific knockout of the insulin receptor in pancreatic beta cells creates an insulin secretory defect similar to that seen in type 2 diabetes. Cell 96 329-339.

Kulkarni RN, Winnay JN, Daniels M, Brüning JC, Flier SN, Hanahan D \& Kahn CR 1999b Altered function of insulin receptor substrate-1-deficient mouse islets and cultured $\beta$-cell lines. Journal of Clinical Investigation 104 R69-R75.

Lenzen S 1979 Insulin secretion by isolated perfused rat and mouse pancreas. American Journal of Physiology 236 E391-E400.

Liljenquist JE, Horwitz DL, Jennings AS, Chiasson JL, Keller U \& Rubenstein AH 1978 Inhibition of insulin secretion by exogenous insulin in normal man as demonstrated by C-peptide assay. Diabetes 27 563-570.

Loreti L, Dunbar JC, Chen S \& Foà PP 1974 The autoregulation of insulin secretion in the isolated pancreatic islets of lean (obob) and obese-hyperglycemic (obob) mice. Diabetologia 10 309-315.

Loubatieres-Mariani MM, Chapal J, Alric R \& Loubatieres A 1973 Studies of the cholinergic receptor involved in the secretion of insulin using isolated perfused rat pancreas. Diabetologia 9 439-476.

Louis-Sylvestre J 1976 Preabsorptive insulin release and hypoglycemia in rats. American Journal of Physiology 230 56-60.

Louis-Sylvestre J 1978 Relationships between the two stages of prandial insulin release in rats. American Journal of Physiology 235 E103-E111.

Lowry OH, Rosebrough NJ, Farr AL \& Randall RJ 1951 Protein measurement with the Folin phenol reagent. Journal of Biological Chemistry 193 265-275.

Ma MYH, Wang J, Rodd GG, Bolaffi JL \& Grodsky GM 1995 Differences in insulin secretion between rat and mouse islets: role of cAMP. European Journal of Endocrinology 132 370-376.

Malaisse W \& Malaisse-Lagae F 1968 Effets du glucose sur la secretion pancreatique d'insuline in vitro, dans differentes espè ces de rongeurs. Annales d'Endocrinologie 29 501-505.

Malaisse-Lagae F, Sener A \& Malaisse WJ 1987 Can desensitization of the $\beta$-cell to glucose be simulated in cultured pancreatic islets? Acta Diabetologica Latina 24 17-25.

Metz SA 1988 Is protein kinase C required for physiologic insulin release? Diabetes 37 3-7.

O'Conner MDL, Landahl H \& Grodsky GM 1980 Comparison of storage- and signal-limited models of pancreatic insulin secretion. American Journal of Physiology 238 R378-R389.

Okada T, Kawano Y, Sakakibara T, Hazeki O \& Ui M 1994 Essential role of phosphatidylinositol 3-kinase in insulin-induced glucose transport and antilipolysis in rat adipocytes: studies with a selective inhibitor wortmannin. Journal of Biological Chemistry 269 3568-3573.

Pagliara AS, Stillings SN, Hover B, Martin DM \& Matschinsky FM 1974 Glucose modulation of amino acid-induced glucagon and insulin release in the isolated perfused rat pancreas. Journal of Clinical Investigation 54 819-832.

Panten U 1975 Effects of alpha-ketomonocarboxylic acids upon insulin secretion and metabolism of isolated pancreatic islets. NaunynSchmiedeberg's Archives of Pharmacology 291 405-420.

Panten U, Christians J, Kriegstein EV, Poser W \& Hasselblatt A 1974 Studies on the mechanism of L-leucine- and $\alpha$-ketoisocaproic acidinduced insulin release from perfused isolated pancreatic islets. Diabetologia 10 149-154.

Pillay TS, Xiao S \& Olefsky JM 1996 Glucose-induced phosphorylation of the insulin receptor. Journal of Clinical Investigation 97 613-620.

Robinson C, Tamborlane WV, Maggs DG, Enoksson S, Sherwin RS, Silver D, Shulman GI \& Caprio S 1998 Effect of insulin on glycerol production in obese adolescents. American Journal of Physiology 274 E737-E743.

Sato Y \& Henquin J-C 1998 The K ${ }^{+}$-ATP channel-independent pathway of insulin secretion by glucose. Diabetes 47 1713-1721.

Seghers V, Nakazaki M, DeMayo F, Aguilar-Bryan L \& Bryan J 2000 Sur1 knockout mice. A model for $\mathrm{K}_{\mathrm{ATP}}$ channel-independent regulation of insulin secretion. Journal of Biological Chemistry 275 9270-9277. 
Soll AH, Goldfine ID, Roth J, Kahn CR \& Neville DM 1974 Thymic lymphocytes in obese (ob/ob) mice: a mirror image of the insulin receptor defect in liver and fat. Journal of Biological Chemistry 249 4127-4130

Straub SG \& Sharp GWG 1996 A wortmannin-sensitive signal transduction pathway is involved in the stimulation of insulin release by vasoactive intestinal polypeptide and pituitary adenylate cyclase-activating polypertide. Journal of Biological Chemistry 271 1660-1668.

Tamemoto H, Kadowaki T, Tobe K, Yagi T, Sakura H, Hayakawa T, Terauchi Y, Ueki K, Kaburagi Y, Satoh S, Sekihara H, Yoshioka S, Horikoshi H, Furata Y, Ikawa Y, Kasuga M, Yazaki Y \& Aizawa S 1994 Insulin resistance and growth retardation in mice lacking insulin receptor substrate-1. Nature 372 182-186.

Van Haeften TW, Boonstra E, Veneman TF, Gerich JE \& van der Veen EA 1990 Dose-response characteristics for glucose-stimulated insulin release in man and assessment of influence of glucose on arginine-stimulated insulin release. Metabolism 39 1292-1299.

Virkamäki A, Ueki K \& Kahn CR 1999 Protein-protein interaction in insulin signaling and the molecular mechanisms of insulin resistance. Journal of Clinical Investigation 103 931-943.

Vlahos CJ, Matter WF, Hui KY \& Brown RF 1994 A specific inhibitor of phosphatidyinositol 3-kinase, 2-(4-morpholinyl)-8phenyl-4H-1-benzopyran-4-one (LY294002). Journal of Biological Chemistry 269 5241-5248.

Yeh J-I, Gulve EA, Rameh L \& Birnbaum MJ 1995 The effects of wortmannin on rat skeletal muscle. Journal of Biological Chemistry $2702107-2111$.

Zawalich WS 1996 Regulation of insulin secretion by phosphoinositidespecific phospholipase $\mathrm{C}$ and protein kinase $\mathrm{C}$ activation. Diabetes Reviews 4 160-176.

Zawalich WS \& Zawalich KC 1988 Phosphoinositide hydrolysis and insulin release from isolated perifused rat islets. Studies with glucose. Diabetes 37 1294-1300.

Zawalich WS \& Zawalich KC 1996a Regulation of insulin secretion by phospholipase C. American Journal of Physiology 271 E409-E416.
Zawalich WS \& Zawalich KC $1996 b$ Signal transduction in isolated islets from the ob/ob mouse: enhanced sensitivity of protein kinase $\mathrm{C}$ to stimulation. Biochemical and Biophysical Research Communications 223 618-623.

Zawalich WS \& Zawalich KC 2000 A link between insulin resistance and hyperinsulinemia: inhibitors of phosphatidylinositol 3-kinase augment glucose-induced insulin secretion from islets of lean, but not obese, rats. Endocrinology 141 3287-3295.

Zawalich WS, Karl RC, Ferrendelli JA \& Matschinsky FM 1975 Factors governing glucose induced elevation of cyclic $3^{\prime} 5^{\prime}$ AMP levels in pancreatic islets. Diabetologia 11 231-235.

Zawalich WS, Zawalich KC \& Rasmussen H 1989a Cholinergic agonists prime the $\beta$-cell to glucose stimulation. Endocrinology 125 $2400-2406$.

Zawalich WS, Zawalich KC \& Rasmussen H 1989 b Interactions between lithium, inositol and mono-oleoylglycerol in the regulation of insulin secretion from isolated perifused rat islets. Biochemical Journal 262 557-561.

Zawalich WS, Zawalich KC, Ganesan S, Calle R \& Rasmussen H 1991 Influence of staurosporine on glucose-mediated and glucoseconditioned insulin secretion. Biochemical Journal 279 807-813.

Zawalich WS, Zawalich KC \& Kelley GG 1995a Effects of short term culturing on islet phosphoinositide and insulin secretory responses to glucose and carbachol. Acta Diabetologica 32 158-164.

Zawalich WS, Zawalich KC \& Kelley GG 1995b Regulation of insulin release by phospholipase $\mathrm{C}$ activation in mouse islets: differential effects of glucose and neurohumoral stimulation. Endocrinology 136 4903-4909.

Zhao AZ, Bornfeldt KE \& Beavo JA 1998 Leptin inhibits insulin secretion by activation of phosphodiesterase 3B. Journal of Clinical Investigation 102 869-873.

Received 7 November 2001

Accepted 5 April 2002 